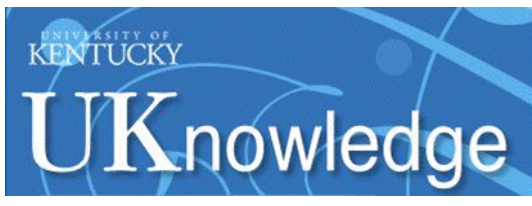

University of Kentucky

UKnowledge

Geography Faculty Publications

Geography

Fall 2014

\title{
The Veil, Desire, and the Gaze: Turning the Inside Out
}

\author{
Banu Gökarıksel \\ University of North Carolina
}

Anna Secor

University of Kentucky, ajseco2@uky.edu

Right click to open a feedback form in a new tab to let us know how this document benefits you.

Follow this and additional works at: https://uknowledge.uky.edu/geography_facpub

Part of the Geography Commons

\section{Repository Citation}

Gökarıksel, Banu and Secor, Anna, "The Veil, Desire, and the Gaze: Turning the Inside Out" (2014). Geography Faculty Publications. 3. https://uknowledge.uky.edu/geography_facpub/3

This Article is brought to you for free and open access by the Geography at UKnowledge. It has been accepted for inclusion in Geography Faculty Publications by an authorized administrator of UKnowledge. For more information, please contact UKnowledge@lsv.uky.edu. 
The Veil, Desire, and the Gaze: Turning the Inside Out

Notes/Citation Information

Published in Signs, v. 40, no. 1, p. 177-200.

(C) 2014 by The University of Chicago. All rights reserved.

The copyright holders have granted the permission for posting the article here.

Digital Object Identifier (DOI)

http://dx.doi.org/10.1086/676897 


\section{The Veil, Desire, and the Gaze: Turning the Inside Out}

n his first lecture of 1972, in the seminar series known as Encore, or On

Feminine Sexuality, Jacques Lacan relayed the following story:

I can tell you a little tale, that of a parakeet that was in love with Picasso. How could one tell? From the way the parakeet nibbled the collar of his shirt and the flaps of his jacket. Indeed, the parakeet was in love with what is essential in man, namely, his attire (accoutrement). The parakeet was like Descartes, to whom men were merely clothes, walking about. Clothes promise debauchery when one takes them off. But this is only a myth. ... To enjoy a body when there are no more clothes leaves intact the question of what makes the One, the question of identification. The parakeet identified with Picasso clothed.

The same goes for everything involving love. The habit loves the monk, as they are but one thereby. (Lacan 1998, 6)

The parakeet loves Picasso, which means that he loves him clothed, that indeed he loves his clothes. Lacan performs a reversal: clothes are not the superficial aspect of a subject but that which is essential. Likewise for Gilles Deleuze, "the clothed lies underneath the bare" $(1994,289)$. In our research with women who veil-that is, who cover their hair and parts of their bodies in various styles according to professed Islamic codes of modest dress-we have become especially interested in the question of clothes in relation to the body and the subject. What if, as Lacan argues, the unity of identity is constructed on the surface? Such a wager builds upon Sigmund Freud's enigmatic assertion that "the ego is first and foremost a bodily ego; it is not merely a surface entity, but is itself the projection of a surface" ([1923] 1960, 20). Following Freud, Didier Anzieu (1989) has argued that the skin organizes the ego by providing a mental image of the self, as a surface enclosing psychical contents. Yet while the importance of the skin as a sensory organ and the envelope of the body is indisputable, it must be admitted that the body enters the field of vision, for the most part, clothedwearing what Edmund Bergler calls its "improved skin" (1953, xxiii). Indeed, Anne Hollander, in her work of art history, Seeing through Clothes (1975), argues that the purpose of dress is "to contribute to the making 
of a self-conscious individual image, an image linked to all other imaginative and idealized visualizations of the human body" (xiv). The image of the self, the ideal ego, is clothed; the identity (Picasso, monk) depends upon the dress.

If clothes are the image of the self, then what kind of self is mapped upon the veiled surface? Veiling has inspired much political, social, and psychoanalytic critique, but the perspectives of women who veil are rarely the impetus for these theories. Our work is based on focus groups and interviews with over eighty veiled (tesettürlï) women in Istanbul and Konya. ${ }^{1}$ In the context of the rise of fashionable veiling in Turkey, we argue that veiling does not simply mean blocking the gaze but is instead a matter of mobilizing a particular visual regime, one that enacts its own aesthetics and ethics. Veiled women are not invisible; they are visible in a particular manner, and they are active participants in producing that visibility. We argue that for veiled women, the clothed body is the site of a project to map an ideal of harmony that has both aesthetic and ethical registers. This ideal of a unified, harmonious appearance (which, we will suggest, exists somewhere between the psychoanalytic ego ideal and an Islamic ideal of the self) is ruptured by materialist and corporeal desire, what women call nefis. Veiling fashion, we argue, both incites nefis/desire and works as a means of governing it.

Our work departs from previous psychoanalytically inflected scholarship on the veil. Much of this work has begun from a premise similar to the one articulated by Ellie Ragland: "The woman under the veil is extracted from the spectrum of the gaze" $(2008,13)$. As an object within orientalist fantasies, the veil appears as a fetish object, a barrier to the (male) recognition of loss (castration), and a disavowal of sexual difference (Alloula 1986; Copjec 1989; Yeğenoğlu 1998). Within accounts that focus on the veiled subject herself, veiling is usually understood as a system of control that removes women from the field of the gaze, limiting their visibility in the public arena and protecting them from shame (Copjec 2006). From this perspective, the

\footnotetext{
${ }^{1}$ We use the terms "veil" and "veiling" in this article to indicate an Islamic system of modesty in dress ( hijab in Arabic or tesettür in Turkish). Veiling in general may range from just covering the hair with a headscarf to fully covering the body. In the context of our work, the women we talked to described themselves as covered (kapali) as opposed to uncovered or open $(a c ̧ \imath k)$ and wore headscarves paired with outfits that, to varying degrees, attempted to conform to an idea of women's modesty in Islam. Like most veiled women in Turkey, they did not cover their faces, and they did not wear enveloping outer garments (such as the abaya, or in Turkish, the çarşaf). Rather, they often wore overcoats (pardesï) or tunics over long skirts or pants. According to a nationwide survey conducted in 2006, about 50 percent of Turkish women covered their hair in public (Çarkoğlu and Toprak 2006, 24).
} 
veil has been read either as preventing women from experiencing themselves as subjects (insofar as shame is the "proper emotive tonality of subjectivity" [Agamben 1999, 110; see also Copjec 2006]) or as an interruption of the masculine fetishization of women's bodies (Krips 2008). Fethi Benslama, in his book Psychoanalysis and the Challenge of Islam (2009), argues that the veil not only covers the woman but blinds her own eye-the one that commands the heterosexual male gaze. Despite the range of psychoanalytic interpretations only briefly touched on here, in every case, the veil is understood to negate women's participation within the scopic realm.

Such arguments seem to give veiling exceptional status - as though it is not clothing but an absolute barrier to women's visibility and presence, as though veiling is the only clothing that covers the body, and as though that which must be seen in order for seeing to really take place is the body rather than the clothes. Yet veiled women are still visible, and they are still able to see. Malek Alloula (1986) makes this point with regard to the colonial French photographer; the veiled women whom he photographs can still see him, even when he cannot see what he wants to see of them. And as Emma Tarlo (2010) writes, veiling is part of being visibly Muslim; it marks an active participation within the domain of public visibility. Women do not become invisible when veiling; they are simply visible in a particular way.

Instead of casting the veil as something that blocks the gaze or removes women from the scopic field, our work looks at how the veiled subject maps herself within the field of the gaze. When Lacan refers to the field of the gaze, he directs our attention to how visibility depends not just on one's own eye but on a preexisting gaze. The gaze for Lacan is not the same as the eye or the look. While the subject consciously looks, the gaze is that which sees the seer. Perhaps the best way to understand this split between the look and the gaze is through Lacan's formula, "I see only from one point but in my existence I am looked at from all sides" (Lacan 1998, 72). The eye is the point from which I see, but the gaze is that which I understand to illuminate me within the scopic field. In Lacan's words, "What determines me, at the most profound level, in the visible, is the gaze that is outside" (106). Yet the Lacanian gaze is not simply a projection of the gaze of others turned back upon the subject. Insofar as the gaze makes the subject appear (as whole, as herself an object/subject), the gaze is itself the object-cause of desire in the scopic field, the hook upon which the fantasy of visibility hangs. Within this field of the gaze, the subject plays with her own image, mapping herself (clothed and idealized) within the picture according to the coordinates of her own desire. We aim to show how veiling works as part of this play. 
One of the reasons why psychoanalytic treatments of the veiled subject have fallen short, it seems to us, is that they have tended to treat the veil as a symbolic object rather than as part of women's lived subjectivities. So one thing that we can offer to this discussion is an analysis of how the veil becomes part of women's self-formation. Recent anthropological scholarship on veiling demonstrates the significance of this practice to the cultivation of piety and the making of an ethical self (Brenner 1996; Saktanber 2002; Mahmood 2005). We build on this scholarship to analyze the work of veiling for women's formation of the self. Our focus on veiling as fashion also connects us to a growing literature on the rise of fashionable styles of veiling in Turkey as well as globally. ${ }^{2}$ Rejecting the labels "ethnic dress" or "folk costume" traditionally used to describe Muslim women's attire (Akou 2007), this literature places the emergence of the fashionable veil within a broader market of Islamically inflected goods, an "Islamic consumptionscape" (Sandıkçı and Ger 2001, 146) that includes a range of products from halal food, to Muslim women's novels and magazines, to headscarves in the trendiest colors and patterns of the season (Gökarıksel and McLarney 2010). Despite the marketing of such products as "Islamic," the Islamicness of such commodities remains fiercely debated (Navaro-Yashin 2002; Gökarıksel and Secor 2010b).

The research on fashionable styles of veiling has sought to understand what it means for women to wear veiling fashion and how they negotiate conflicting ideals of piety, beauty, modesty, femininity, and national identity in a variety of contexts. ${ }^{3}$ Fashionably veiled women constantly navigate the multiple social and cultural signification of their clothing, which has been variably associated with politics, aesthetics, fashion, and class status. Wearers of the styles invest considerable time, energy, and money in their clothing, headscarves, and accessories (Sandıkçı and Ger 2005; Gökarıksel and Secor 2010a, 2012a). At the same time, the fashion industry and selfidentified Muslim women's lifestyle magazines devise strategies to turn Islamic virtue into economic value and vice versa (Jones 2010; Lewis 2010). Thus, this scholarship provides insights into the role of veiling fashion in the commodification of Muslim identities as well as the making of pious Muslim femininities. Yet we find the question of visibility and how it connects with the governance of desires and subject formation implicitly present but insufficiently addressed in this body of work. Here we engage psychoanalytic

\footnotetext{
${ }^{2}$ On veiling in Turkey, see White (1999), Sandıkçı and Ger (2001, 2005, 2007, 2010), Kılıçbay and Binark (2002), Navaro-Yashin (2002), and Lewis (2007). On veiling globally, see Akou (2007) and Moors and Tarlo (2007).

${ }^{3}$ See Klepp and Storm-Mathisen (2005), Jones (2007), Moors (2007, 2009), and Schulz (2007).
} 
perspectives on the relations between the subject, the gaze, and desire to deepen our analysis of veiled women's visibility and subjectivity. We also aim to contribute to the limited treatment of the veil within psychoanalytic literature, thus putting this literature in conversation with anthropological and geographical research.

In our fieldwork research in the summer of 2009 we conducted six focus groups with consumers of veiling fashion and one with sales assistants who work on the retail side of veiling fashion in Turkey. Each group meeting was composed of eight women, organized by age-group and socioeconomic status, and lasted about two hours. Five of the six focus groups with consumers were in Istanbul, and one took place in Konya, while the focus group with sales assistants (all of whom were also veiled) was in Istanbul. This research is part of a larger project that included interviews with producers, designers, and workers engaged in the veiling fashion industry. In the focus groups with women wearers of these styles, we asked a series of open-ended questions about clothing styles, consumption practices, and faith. Thus, our analysis focuses on what women say about their feelings and practices and how they represent who they are rather than our observations of their daily practices. We conducted the focus groups with the help of a moderator and a research assistant taking notes. All focus groups were recorded and transcribed. All of us (the two researchers and the assistants) who conducted the interviews are women (Turkish and American), and none of us wear the headscarf.

\section{Veiling fashion in Turkey}

The importance of the visible crystallizes when we talk about veiling as fashion. Fashionable veiling immediately upends the idea of the veil as a blank barrier, a "death shroud" (Ragland 2008, 11) or a "uniform" that disappoints the photographer with its "deficiency of expression" (Alloula 1986, 11; see also Krips 2008). In contrast, fashion promises compulsive innovation and self-expression; rather than dead desire, fashion represents the constant renewal of desire in the field of consumption (Baudrillard 1981; Wilson 1985). Fashion is inherently linked to the visual; like art, it is part of a "perpetually idealizing vision" that "appeals to the imagination through the eye" (Hollander 1975, xvi). Taking shape through an interplay of visual references, fashion is constituted within the exchange of looking and desiring that defines the field of the gaze. In Rebecca Arnold's (2001) words, "Fashionable dress is a route to constructing visual identities that can be aspirational or subversive," identities that consumers construct "in reference to the images that surround them" $(13,92)$. 
Veiling fashion is always designed to be looked at; it is outerwear, worn to traverse public spaces. Like fashion more broadly, fashionable veiling is defined by cycles of changing cuts, colors, and fabrics, "visual rhythms of delight, indifference, and distaste" (Hollander 1999, 112). Women in our focus groups spoke knowledgeably about that season's fashionable arrangement for buttons, zippers, hemlines, pleats, and sleeves. The fashion cycle is swift and encompasses all elements of the dress; in the words of one sales assistant, "For example, the headscarf I'm wearing is a 2009 model, as anyone who follows the fashion would know. If I wear this headscarf next year, there will be people who would say, 'She's wearing last year's fashion.' There are people who would comment on someone wearing last year's overcoat." Both the alacrity of change and the sense of obligatory renewal were evident in women's complaints about high prices being followed by end-of-season sales; as one woman put it, "Why should I wear last season's styles?”

Veiling in Turkey began to be recognized as fashion over the past thirty years. This is not to say that headscarves and modest dress had not been subject to fashion previously, but it is to mark the emergence, since the 1990s, of a distinctive look consisting of ever-shifting styles of scarves and coat or tunic combinations (Kılıçbay and Binark 2002; Saktanber 2002). Designer labels, fashion shows, and Paris-inspired styles have all contributed to a vibrant domestic industry catering to an increasingly visible Islamic bourgeoisie. Today in Turkey, veiling fashions are displayed on catwalks, in store windows, in the pages of magazines, on television shows, and, most of all, on the streets of the city. Yet veiling fashion is far from a perfect concoction of piety and style. Not only do women themselves struggle to reconcile the demands of modesty with the imperatives of fashion (Gökarıksel and Secor 2010a, 2012a), they also find themselves under constant public scrutiny from Islamists and secularists alike. Veiling fashion consumers have been accused of hypocrisy, moral weakness, and shallowness. ${ }^{4}$ Further, because the new style of veiling emerged in tandem with the rise of Islamist political parties that agitated for the removal of headscarf bans in public spaces, its wearers are often associated with politics in Turkey and are accused of agitation. In the midst of these controversies, veiling fashion has attained a heightened visibility. Thus, rather than blocking women from view, fashionable veiling subjects women in Turkey to a particular kind of political, moral, and aesthetic scrutiny.

${ }^{4}$ See, e.g., Aktaş (1991, 1995), Ceylan (1992), Çiftçi (1993), Şişman (2001), Eygi (2005, 2009), and Hakan (2008). 


\section{Veiling, looking, and desiring}

Jale: When they [men] see a well-dressed woman who takes care of herself, they look. I mean the eye sees what it sees. Sometimes even I turn around and look when I see someone beautiful.

Saliha: But I think it's us who provoke them [men], we're provoking them.

Esra: I agree. It's definitely all women's doing.

Saliba: Yes, absolutely. They dress in a way that makes even me look. Imagine a beautiful woman, for instance, a really beautiful woman and she has exhibited all of her beauty. I find myself staring after her.

Moderator: So are there veiled women at whom you find yourself staring as well?

Jale: Of course, the headscarf, the overcoat, the matching colors, the shoes, the purse.

If looking is the hook for desire (Lacan 1998; see also Ghazali 1995), then the scopic regime of fashionable veiling should be understood in terms of a particular dispensation of looking and desiring. On the one hand, this looking-desiring dispensation is similar to that of fashion in general: the objects that compose the fashionably veiled image (the latest scarves, the new cut of a jacket, the trendiest fabrics and colors) circulate across bodies, billboards, television, shop windows, and so on. In the dialogue above among young, upper-middle-class women in Istanbul, Jale, a thirty-yearold woman who wore a combination of a blue headscarf and a blue doublebreasted coat, points to just that: the objects that go into veiling fashion ensembles capture her eye and provoke her desire for the image on display. In this process of looking and desiring, the mystique of the commodity and the allure of the fashionable image are enhanced. For women spectators, this allure, as Diana Fuss argues in her discussion of fashion photography, involves "neither immediate identification nor unmediated desire but rather a complicated and unstable exchange between already mediated forms" $(1994,224)$. The scopic regime of fashionable veiling, like fashion in general, hinges on women as spectators using consumption to mediate between their identification with the fashionable image and their desire for the image. How this complex relationship (triangulating commodities, subjectivities, and the image) plays out in the arena of veiling fashion is perhaps best illustrated with another dialogue from our focus group with young (late twenties to late thirties) lower-middle-class women in Istanbul:

Ayşe: The other day, for example, I saw this scarf in a commercial and I absolutely loved it. I said, "Oh, I must definitely go and get it." It 
was an Armine [a well-known Turkish brand name] scarf. It looked so amazing on the model that I thought it would look similar on me as well. I went ahead and bought it, I loved it.

Moderator: What else affects you?

Özge: For me generally, it's like, I went searching for a scarf but I couldn't find the scarf that I wanted. I was trying to find something to go with my outfit. Finally I gave up and I started walking home. Suddenly I saw this lady walk past me. That's it! She was wearing the scarf I needed for my outfit! I had gone around and visited ten stores to find it with no avail, and I was returning home all upset when I saw exactly what I wanted on her.

Ayşe: Oh my God, the same thing happened to me.

Özge: So I ran to her and I was like, "Where did you get it?" "If you want," I said, "I'll give you a brand new scarf in exchange for yours." And that's what I ended up doing!

Aysse: The same thing happened to me with a friend of my sister's. I was like, "That scarf would go so well with my overcoat." I had looked for it in a couple of stores but wasn't able to find it. Then I saw this photograph of my sister and her friend, and I told my sister to ask her friend where she got her scarf. It was a friend of hers from the university. She found out for me, I went to the same store and bought the exact same scarf.

Moderator: So you see things on each other, on the streets, and on commercials.

Ayşe: And sometimes what they do is they tuck the brand name underneath, instead of displaying it at the back, which I hate. The other day, I saw a scarf on someone, I looked from behind and couldn't see the brand name. If I could've seen it, I'd go and get it.

Moderator: Ah, you look for the brand.

Ayşe: Yes, for example, you tie the scarf so that the brand name is visible, whether it's Aker or Vakko or whatever. My God, I tried so hard to be able to tell hers, from the back but no, she had tucked it in. I couldn't walk up and ask either, I was too shy. Usually it's there, though, you can see it. That also has an effect on the way to tie your scarf.

In each of the anecdotes that Ayşe and Özge (both of them housewives in their late twenties) share in the conversation above, the veiled woman who is seen - in a commercial, on the street, in a photograph-incites a desire and an identification. The model looks amazing in that scarf; if Ayşe wears the scarf, she will look like the model. The woman on the street 
projects the image that Özge was endlessly seeking to achieve; what was impossible - ten stores, a wasted afternoon-is perfected on the head of this other woman, whom Özge then accosts and actually de-scarfs! And the image that Ayşe has in her head of the perfect scarf to go with her overcoat is reflected in the photograph of another woman, a university student, a friend of her younger sister. Finally, there is a demand for visibility - the brand name must be displayed, for this is the law of fashion and its circulation. In all of these ways, it is clear that, like fashion in general, the images and commodities of veiling fashion circulate through the interplay between looking and desiring.

On the other hand, veiling fashion is not fashion in general; the dispensation of looking and desiring in veiling fashion is shaped by a particular ethical practice, that of Islamic modesty. To be clear, veiling is not unique in its association with modesty. On the contrary, clothes have long been understood to operate within the contradictory imperatives of modesty and exhibition (Flugel 1930). Yet the question of how modesty is articulated in relation to the gaze is especially pronounced when veiling is indexed to Islam. Importantly, the question of how and to what degree a woman should cover according to Islam is not one with a single, agreed-upon answer, although naturally there are those who believe that their own interpretation is indisputably correct. For the most part, women in our focus groups recognize the contingency of these interpretations, pointing out that not only do readings of the Koran differ but what counts as modest in one era is risqué in another.

Among the women we talked to, the fundamental purpose of veiling was consistently expressed as "not to attract attention." Given this emphasis on not attracting the eye, it is easy to understand why veiling has been widely interpreted as an intervention in the power that women possess to command the male gaze, as something intended to interrupt the heterosexual male's scopophilia (Mernissi 1987; Benslama 2009). Yet while this formulation emphasizes the male looker, veiling as fashion works upon women's spectatorial subjectivity (Fuss 1994). Further, while it appears that veiling and fashion could not be more opposed to each other when it comes to the question of the gaze, they are lived within a common realm, a single visual field within which wearers of these styles operate both as spectators and as part of the spectacle. We find that the practices of veiling fashion take place within the tense interplay between the scopophilia of fashion and the modesty of veiling (Gökarıksel and Secor 2010a, 2012a, 2012b).

That looking and desiring between women can lead to anxiety is demonstrated in the following story. In a focus group with older women in Istanbul, Arzu, a forty-three-year-old housewife who wore a small, polka- 
dotted headscarf to the focus group, confessed, "There was a covered lady [at the bus stop], but she had dressed so beautifully even I was tempted to look at her." She went on to describe how the woman was harassed by men waiting at the bus stop, one of whom said, "We see the open [nonveiled] ones anyway, but we are curious about these closed boxes." Arzu expressed her dismay and addressed the object of this attention in her absence, "You're beautiful and you're dressed so well! You have all this makeup on that even as a woman attracts my attention. How could a man not look at you? I was mad at her for being so." In an uncomfortable way, Arzu identified with the male gaze; she too felt the pull to look at this woman with her beautiful clothes and makeup. Like the parakeet, Arzu (and the men) love the woman clothed; in fact, her clothes are the object cause of desire at the bus stop. While Arzu is mad at the well-dressed woman for being the proximate cause of this awkward tangle, she is also using this story to make a point about the ambivalence of veiling fashion and the line that should not be crossed, lest the "closed boxes" become the most alluring ones of all.

Instead of removing women from the field of the gaze, veiling as fashion inserts them into the scopic field in a particular way. Veiling does not work simply to arrest the play of looks and desires; instead, as fashion, it instigates a frenetic circulation. Yet the practices of veiling fashion are not reducible to the practices of fashion in general because veiling is part of an ethical project of the self with an Islamic moral telos. Thus, what is at stake in veiling fashion is an image of the self that is not only fashionable but also pious. This is why we say that veiling inserts women into the scopic field in a particular way; the gaze that illuminates the veiled subject is not only social but also theological. In the following section, we turn to the question of what ideal self the veiled body seeks to mirror.

\section{The ideal of harmony and the aesthetics of veiling}

Veiling fashion (as that improved skin, that identity mapped on the surface of the body) calls forth an exacting aesthetic regime. On the one hand, women talk about how the styles of veiling are more exciting, attractive, and even joyous than the styles that uncovered women wear. At the same time, women feel that veiling makes greater demands on them than noncovered dress would. Many women talk about their own transition to veiling in terms of a transition to taking more care with their appearance, comparing how little thought they put into their dress when they were uncovered to the amount of attention to detail that veiling fashion requires. The following discussion occurred in our focus group with consumers in Konya: 
Melike: Covering has so many details, headscarves for example. If I were open I would wear a t-shirt, jeans, and that's all. And sneakers. But when you are a covered person there are so many details you have to take into account, from your stockings to your headscarf.

Özlem: For example, yesterday I was about to go out, I thought to myself "What will I do, what will I do, what will I wear." I can't do much because we have exams right now. I wore my jeans, my shirt, and I said, "I would go out like this if I were open." But instead I thought about it for hours. . . . For us, it's really a lot of pressure.

Melike: I mean, there are so many details. You can't wear shortsleeved shirts, you have to wear a top underneath, and then you'll wear something [on top] like a sleeveless dress. So many details, it's a lot of work. . . . It's more costly for the covered.

Nalan: Open people spend less.

Emel: For example, our brand [of] overcoats are pretty expensive.

To pull off the look, women find themselves both putting time and thought into assembling their outfits each day and also (in the words of Özlem) "constantly shopping." For Emel, the brand-name (designer) overcoat is practically a necessity of the look, not an option. In many of our discussions, women explained that sneakers look gauche with an overcoat; clothes that are comfortable and casual are hard to integrate with the more ladylike images of the fashionable veiled woman that circulate on billboards and in advertisements. That said, there are plenty of examples, within our focus groups and visible on city streets throughout Turkey, of women who push these boundaries, and sneakers are not uncommonly seen with veiling fashion ensembles; it is a matter of taste. Women described their own attention to detail, the importance of matching handbags and shoes, of varied textures and harmonious arrangements of color designed to complement their complexions, the shapes of their faces, and the dimensions of their bodies. In a discussion in the Konya group about pinning the scarf, Özlem, for example, explains that her pins are placed to minimize the look of what she calls her "chubby cheeks." And in another focus group in Istanbul, when discussing the appropriate length for an overcoat, women's feelings about whether or not they could wear certain styles reflected both their ideas about appropriate modesty and their sense of the aesthetic implications - for example, that a short overcoat might look better on a taller person. Even the question of loose- or tight-fitting clothes was approached both in terms of modesty and in terms of women's individual, aesthetic preferences for how much fabric they felt their frames could pleasingly carry. Çağla, a young woman who not only wears veiling fashion but also works as 
a sales assistant in an Istanbul boutique, situates questions of beauty, care, and attention to detail within an Islamic register: "[In Islam] the woman is always a jewel (ziynet); ... A woman is all care, from tip to toe; there's care for everything, even the toenail of a woman. In that sense, the woman is always beautiful, she is creation (fitrat); she is the ornament (sïs). In this sense, Islam wants the woman to be plain and good looking." How to navigate this demand - to be both modest and beautiful - seems to be the central problem of practices of veiling fashion.

Perhaps the most exacting aesthetic regime of all is associated with the headscarf and its fastening. When it comes to covering the head, veiling fashion in Turkey demands that no strand of hair should escape the smooth surface of the scarf. In fact, this complete covering of the hair and neck arose with veiling fashion in the 1980s and 1990s in distinction to more traditional modes of head covering in Turkey. New accessories, such as bonnets and pins, have been introduced in order to produce a sleek and perfect look. While many in Turkey have talked about the political significance of pinning the scarf in certain ways, women in our focus groups, while aware of these discourses, maintained that, for themselves at least, the pins are functional rather than politically symbolic. Scarves, especially silk ones, can slip, so pins and bonnets ensure both the aesthetic perfection of the look (slipping scarves are considered sloppy) and help women fulfill the imperative to show not a single strand of hair.

The aesthetic ideal of veiling fashion is that of harmony-harmony between elements of the dress, harmony between appearance and conduct, and harmony between appearance and belief. Incongruities of dress such as miniskirts, bright red lipstick, or colorful nail polish worn with headscarves were generally considered aesthetic outrages, a critique that included an ethical dimension. Indeed, whether a particular style is a sin against God or against aesthetics is often a blurry area. For example, women criticized the recent practice of padding the scarf to change the shape of one's head. One criticism was from an Islamic perspective, concerning the possible sin of pretending to have a lot of hair piled underneath, while a second criticism focused on the aesthetics of the elongated, alien shape created. Both of these critiques, one ethical and the other aesthetic, were presented and accepted by the group as equally compelling reasons for not following this latest fad.

The ideal of harmony often concerned which parts of the body could be uncovered while others were not. In a focus group with upper-middleclass younger women in Istanbul, Esin (who described herself as süslï kapal, or "fancy-covered") explained that while she always covers her head, in the summer she might wear short sleeves. Other women in the 
group censured her, asserting that one must not wear even quarter-length sleeves with a covered head or show one's legs when draping one's shoulders. Once you cover your head, women explained, you have to follow certain rules of modest dress. Looking at a fashion photo of a woman wearing a headscarf and a skirt with a high slit, a member of our teenaged focus group in Istanbul stated simply, "she should either take off the scarf or cover her legs."

Beyond bringing consistency to elements of dress, the harmony of veiling extends to an ideal of seamlessness between conduct and appearance; veiling requires a particular bodily dispensation, a way of moving and behaving considered appropriate to the look. As a nineteen-year-old woman in our youngest group put it, "If you're going to cover, you should also watch how you act, how you carry yourself." Other women concurred, saying that they too watch how they act and are more particular about their comportment than they were when they were uncovered. This concern for consistency, particularly among the youngest of our participants, was often linked to their discomfort under what they perceive as a critical public gaze. Because veiling is controversial in Turkey, women felt that the secular public was constantly alert for signs of inconsistency or hypocrisy among the covered sector - and indeed, stories of covered women seen making out with boyfriends in the parks are very popular among secularist critics. Thus, part of what women object to regarding inconsistent dress and behavior is how they see it reflecting on all of those who cover. As one participant put it, "the soft spot of a covered person" comes to be generalized to the whole group of veiling fashion wearers.

While veiling fashion was talked about as constricting behavior and even movement (for example, making it more difficult to leap onto a bus), the problem of inconsistent dress was also understood in terms of the ways in which it might interfere with religious practice. Ayşe, the young woman quoted in the dialogue above about chasing down desirable headscarves on the street, explained her view that veiling fashion had gone haywire: "I'm telling you, the other day I saw a girl wearing a miniskirt with her legs out in the open. And then she's gone and tied on a headscarf. Well, I can see your legs! . . . How am I supposed to start my namaz [prayer] with that miniskirt? She's put on a miniskirt, together with the headscarf! How can I go outside with something I can't pray in or walk in the mosque with?" Ayşe's statement expresses a common view and one that was applied to the problem of nail polish as well (it cannot be removed quickly in the ablutions for namaz). Thus, complaints of women's sartorial inconsistencies are not trivial because the aesthetic of veiling fashion is also an ethic. Aesthetic failure - a miniskirt or three-quarter-length sleeves and a headscarf, 
or a scarf elongated by a faux bun-is understood as a failure of ethical practice. Unharmonious clothes visibly map the inconsistencies of the subject, its disintegration.

But beyond harmonizing the elements of the dress, or the dress with one's conduct, women felt that, ideally, veiling practice should harmonize with desire. Esin, for example (the one who wears short sleeves, above) mentioned to the group that she used to go to bars, but now that she is covered she no longer can do this. The women responded to the wistfulness in Esin's statement by querying whether she had chosen to cover of her own accord, since inconsistencies in dress and behavior are often attributed to forced covering. Esin insisted that indeed it was her own choice to cover; in fact, most of her relatives are uncovered. Jale, a woman in the group who clearly prided herself on Koranic knowledge, responded to Esin by saying that she should not want to go to a bar if she is covered-that these are contradictory impulses. Esin accepted this point without protest, saying only that she cannot help having these contradictions within her. When another woman in the same group, Saliha, admitted that sometimes covering just feels like a hassle when she is trying to leave the house with three kids, Jale told her that if she were strong in her beliefs she would not feel that way. For some at least, covering is supposed to mean a certain kind of harmony between the outward image (a veiled woman) and desire (see also Mahmood 2005), but many women acknowledge that this is not always the case in practice.

The ideal of harmony as it functions discursively means that there should be no gap between interior and exterior, between the woman and her clothes. This ideal is thrown into relief by the critiques that veiling fashion consumers level against those women who wear the all-encompassing outer garment, or abaya, called the çarşaf in Turkish. Although on the one hand the çarşaf sets an expectation that the wearer should have achieved a higher level of piety, some veiling fashion wearers argue that the garment creates a suspect inner space. They suggest that women in çarşaf may be hiding bombs, guns, a male body, sexy lingerie, bikinis, or nakedness - orientalist tropes, of course, deployed to portray the çarşaf wearers as "other" and to position veiling fashion wearers in a particular way vis-à-vis the ideal of modern Turkish republicanism (Gökarıksel and Secor 2012b). The critique of women in çarşaf opens up a discursive space between the body and the clothes that becomes the site of danger, sexuality, and hypocrisy. In contrast, the women in our focus groups see their own more form-fitting clothes as closer to the skin and therefore more transparent, revealing not nakedness but a more reliable image of the self. 
The ideal image — unified and harmonized, ethically and aestheticallyis just that, an ideal. It is not something that women talk about having achieved; it is, instead, the pursued object of veiling fashion. Thus, just as Lacan tells us that the gaze-that which illuminates us, sees us where we ourselves cannot - is itself the object-cause of desire in the visual realm, we argue that the looking-desiring dispensation of veiling fashion is set in motion by the ideal image of the perfectly exteriorized self. This elusive image of the self resonates with the psychoanalytic concept of the ego ideal that, in the words of psychoanalyst Peter Blos, initiates a "sustained striving for perfection" that "can never be fulfilled" but "that furnishes a sense of well-being;" the ego ideal, he writes, is "a ceaseless journey without arrival" $(1974,47)$. But also, perhaps more relevantly for those involved, the unified and harmonious ideal image resonates with an Islamic project of the self. In the words of Seyyed Hossein Nasr, "The whole programme of Sufism . . . is to free man from the prison of multiplicity, to cure him from hypocrisy and to make him whole, for it is only in being whole that man can become holy" $(1999,43)$. This is not to say that the women we talked to were necessarily participants in a Sufi order (these are outlawed but functioning in Turkey; see Silverstein 2008), but arguably Sufiinflected ideas of the self are part of the fabric of lived Islam in Turkey. Insofar as this seamlessness (between inner and outer) and harmony (between the elements of appearance, conduct, and desire) are not achieved but rather are part of a project of the self, women explain the central struggle of this project with recourse to a key Sufi concept: nafs, or in Turkish, nefis.

\section{The rupture of nefis}

The concept of nefis orients us within an Islamically inflected idea of the self. Nefis, the soul, is one of three agencies of the self, the others being kalp (heart) and ruh (spirit) (Schimmel 1975, 191; cited in Shaikh 2009, 790). The works of influential classical Sufi thinkers, such as Abu Hamid al-Ghazali's eleventh-century Disciplining the Soul (1995), have focused on nefis and made its discipline central to the path of piety. In Sufism, nefis is responsible for rupturing the unity between God and humankind (Shaikh 2009). Nefis thus initiates a constant conflict within the self; it is the source of inconsistency and the force that causes the disintegration of the self. While ruh pulls one toward God and unity, nefis, "the lower self," distracts one from the path of God, pulling one toward material and egoist desires (Renard 2009, 79-80). The dynamic agency of nefis is power 
seeking, arrogant, and self-indulgent, and sees material objects as meaningful in and of themselves. Succumbing to nefis causes the metaphorical rusting of the kalp (heart), "the center of human spiritual receptivity" in the Sufi schema, and blocks spiritual development (Shaikh 2009,792). But nefis can and must be governed. In fact, the struggle to govern nefis is the greater jihad; the war against one's soul maps the path of the faithful and defines the Islamic project of the ethical self (Ghazali 1995; Kabbani 1998, 41). Nefiscan be subjugated by "persistent remembrance and invocation of God, abstinence from incorrect behavior, performance of good actions, including service to other human beings, and other rigorous spiritual practices" (Shaikh 2009, 792). The spiritual disciplining of nefis puts a person on the path of the gradual purification of the soul and enables her to progress from a condition of being completely driven by nefis to, in due course, being in complete control of nefis. The ethical development of the self is often understood to take place in stages, moving from the initial stage of incitement to evil; to developing a conscience; inspiring more good deeds; finding peace, contentment, and God's acceptance; and ultimately achieving the perfected and fully purified ideal condition of the Islamic self (Renard 2009, 80; Shaikh 2009).

In the discourse of veiling fashion, nefis is the agency that ruptures the unity of the clothed body and the Islamically identified self. While not explicitly referencing Sufism, our participants often refer to nefis in the Sufi vein to identify the power of bodily and material desires over them. They frequently use the common colloquial phrase in Turkish nefsine hakim olmak (governing nefis) to describe their efforts to discipline an overpowering nefis. Restraining nefis is the hallmark of piety in this discourse. Burçak, a twenty-year-old college student, clearly defines the relation between nefis and religiosity in response to our question to the group about whether they see themselves as devout: "The person who can control her nefis is a religious person. We can control part of our nefis, but unfortunately we cannot control it all. God willing (inşallah), we will come to that stage [of complete control].”

Burçak does not claim to be completely devout because she sees herself (and, as hinted by her use of the pronoun "we," other women in the group and likely all women who wear veiling fashion) as not possessing the ability to entirely reign over nefis. According to her, the more a person can rule over nefis, the more religious she is. Veiling is a technique employed in the governance of nefis; it is a practice that ideally orients a woman toward God; serves as a constant reminder of the greater jihad; enables her to work toward harmonizing her appearance, conduct, and piety; and thus helps the cultivation of Islamic virtue (Mahmood 2005; Gökarıksel and Secor 
2012a). But when veiling is inserted into fashion, it participates in the play of looking and desiring material objects and images of fashion. As the central Sufi thinker al-Ghazali (1995) notes, the eye is where desire begins. Fashionable veiling draws the eye, which provokes nefis and makes its subjugation difficult. Burçak admits that she can only partially govern nefis and presents her style-conscious black-and-white ensemble as the embodiment of the part of nefis that she cannot yet control. For her, as for many other participants, nefis is the agency that disrupts the ideal of the Islamic self. The pesky presence of material desires that fashion seems to invigorate makes it impossible to suture the ideal image. At the same time, Burçak still positions herself (and her dress) on the path toward more complete control of nefis and thus of piety.

Burçak thus expresses a conundrum: veiling orients women toward Islamic modesty and piety, yet the material objects and images of fashionable veiling constantly incite nefis, pulling them away from God. The following dialogue among Istanbul sales assistants provides a window into the way that nefis was deployed in relation to this tension between fashion and piety:

Cağla: As we are all Muslims here, we're all covered. We can't let our nefis guide us. If that happens, we'll lose our faith, God forbid. As my colleague mentioned, I like purple and I wear it, but that doesn't mean this is Islam or that this is right for Islam. No way. I wear purple because I like it, because it pleases me. But it's different when you face God. (Allah katında farklıdır.) ... There is veiling because we have Islam. In other religions there are other clothes. Nuns, for example, wear certain garments; lay people, others, don't wear those. We wear these not because it's a requirement of our religion but because we're human and weak, we are dressed like this [in veiling fashion] right now. However, we cannot put our nefis forward and say, "This is right." So yes, we're doing this, but whether it is right or not will be Allah's call.

Fatma: We try to discipline our nefis.

Cagla: Islam draws a certain line, and people must obey that. And in colors, one follows custom. In present-day Turkey, there is no restriction of color because people wear such colorful, showy things. Of course it's wrong. [It doesn't mean it's right] just because that's the way it is in Turkey. . . . It all comes down to nefis. All of us sisters here cover ourselves because we're Muslims; that's what we are saying. But wearing colorful headscarves ... for example, the Koranic verse tells us, "Wear your headscarf wide over your shoulders." Though I want to, my nefis tells me to make a cute bow.

Gül: What we mean by nefis is the reflection of our style and colors. 
For Çağla, veiling is unquestionably for Islam, and there are certain undisputable rules about modesty. Veiling puts her on the path of the faithful and enables her to identify with other veiled women as Muslim sisters. Çağla seeks a universal understanding of modesty in the Koran. However, she is quick to point out that knowing what Islamic modesty requires does not necessarily mean complying with this requirement. Çağla knows her headscarf should drape loosely over her shoulders, but her nefis makes her wear it in the latest fashion, in "a cute bow."

While veiling fashion companies market the ever-changing colors and cuts of their products as seamless confections of Islam and fashion, Çağla (like other women in our focus groups; see Gökarıksel and Secor 2010b) rejects the idea that fashion and piety can be so easily melded. Despite her understanding of Islamic modesty, she bluntly states that her own purple clothes cannot be justified according to Islam. Rather than arguing that as long as her hair and body are covered, wearing purple does not violate the principle of modesty (a strategy producers use in defense of their coral reds and neon pinks), Cağla says that she simply likes the color and wears it, knowing that her veiling may not be fully Islamically appropriate. The prevalence of an increasing diversity of styles and colors in veiling fashion in Turkey, she argues, does not mean that they are Islamically acceptable as modest clothing. On the contrary, as Gül puts it, the lively fashions are evidence of untamed nefis. Other focus group participants' comments about the rise of form-fitting styles, pants, and bright colors express a similar skepticism about what has appeared within the realm of veiling in the past ten to twenty years. Further, for Çağla, the failure to recognize the contradiction between Islam and fashion signals a surrendering to nefis. The recognition of the agency of desire, of the failure of the ideal of perfect harmony, thus becomes a part of the ethical project of governing nefis.

Nefis is the imp of fashion. As a psychic agency that pulls women away from their pious ideals, nefis is called upon to explain the rupture between the lived image and the ideal. Veiling orients women toward their ideal of harmony and situates them on the path toward achieving greater control over nefis. As a technology of the self, veiling ideally produces certain kinds of behaviors and desires. At the same time, nefis continually opens up a gap between the projected image of piety and the self. When veiling becomes fashion, the relationship between veiling and nefis is further complicated. Veiling fashion inserts women into an economy of the gaze and material objects that stimulates nefis. In the words of Jale, "It's fashion, there's always something new. When one sees, one wants. It's nefis. Nefis overcomes, and you buy it." Veiling fashion thus both participates in the gov- 
erning of nefis and incites it; this tension animates the project of the Islamic self. Wearers of veiling fashion must navigate this conflict between the styles of veiling fashion as desirable commodities and veiling as a discipline of the soul. The women in our research inhabit this tension; it pervades their everyday practices, through which they map themselves within the field of the gaze.

\section{Conclusion}

The gaze, the image, and the subject are intimately intertwined. According to Lacan, the subject maps herself within the field of the gaze, plays with her own image within the visual field in which she is seen from all sides, but cannot see herself. Unable to see herself from the vantage point of the other, she strives to occupy the position of her own ideal image, to suture the rupture that troubles the ideal of a unified, complete, fully identified self. The ego is thus projected onto the surface of the body and idealized in clothes, that "improved skin" (Bergler 1953, xxiii) essential to identity. Our argument can be outlined as follows: First, women who wear veiling fashion enter into the field of the gaze and are therefore subjects and objects of looking and desiring. Second, within this visual field, veiling fashion becomes part of the production of an ideal image understood in terms of harmony and unity. And finally, the disruption of this ideal is, for the women in our research, attributed to the agency of nefis, the pesky imp of material and corporeal desire whose government is central to the ethical project of the sutured self. Our analysis thus does not aim to impose a psychoanalytic interpretation of the veil as a symbol of this or that but instead to understand the role of veiling (and specifically a particular regime of fashionable veiling in Turkey) in women's own formations of themselves as ethical, pious, and desiring subjects.

The understanding that veiling or not veiling participates in the formation of the self is present in Franz Fanon's essay, "Algeria Unveiled":

We must come back to that young girl, unveiled only yesterday, who walks with sure steps down the streets of the European city. ... The unveiled body seems to escape, to dissolve. She has the impression of being improperly dressed, even of being naked. She experiences a sense of incompleteness with great intensity. She has the anxious feeling that something is unfinished, and along with this a frightful sensation of disintegration. The absence of the veil distorts the Algerian woman's corporal pattern. She quickly has to invent new di- 
mensions for her body, new means of muscular control. She has to create for herself the attitude of an unveiled-woman-outside. . . . The Algerian woman who walks stark naked into the European city relearns her body, re-establishes it in a totally revolutionary fashion. $(1965,59)$

Entering into the scopic regime of the European city unveiled, the $\mathrm{Al}$ gerian woman sees herself being seen in a new way, and this gaze rearranges the very dimensions of her body. And in that distortion, she feels herself to be disintegrating and at the same time recomposing in alignment with a new image. But what was her corporal pattern, by what coordinates did she map her body, what was her desire when she was veiled? Fanon answers this implicit question in one way in his essay, but we answer it in another. In our analysis, we find that women engage in veiling fashion as part of a project to align themselves with an ideal image of a harmonious and unified self-a self in which desires, comportment, and image harmonize in accordance with both ethical and aesthetic ideals. At the same time, like the Algerian woman in Fanon's description, they enter the scopic regime of the city, where they are seen and they look, where they desire and are desired. When Arzu expresses her anger at the beautiful veiled woman at the bus stop, she seems to be caught off balance by the exhibition of the beautiful woman's desire and her capacity as a clothed body to arouse the desires of the others. Rather than removing veiled women from the play of the gaze, veiling fashion is the mark of women's participation in circuits of desire. The surface of the body is not insignificant; it is the site upon which women project their ideal selves, aesthetically and ethically. The path to unity within the self and with God is mapped on the surface of the body, and it is on and through the veiled body that the ongoing struggle for the unity of desire, faith, and image takes place. The veil loves the woman, as they are but one thereby.

Department of Geography

University of North Carolina (Gökarıksel)

Department of Geography

University of Kentucky (Secor)

\section{References}

Agamben, Giorgio. 1999. Remnants of Auschwitz: The Witness and the Archive. Trans. Daniel Heller-Roazen. New York: Zone.

Akou, Heather Marie. 2007. "Building a New 'World Fashion': Islamic Dress in the Twenty-First Century." Fashion Theory 11(4):403-22. 
Aktaş, Cihan. 1991. Tanzimattan Günümüze Kılık, Kıyafet ve Iktidar [Politics and clothing since the Ottoman constitutional period]. Istanbul: Nehir.

- 1995. Mabremiyetin Tükenişi [The end of modesty]. Istanbul: Nehir.

Alloula, Malek. 1986. The Colonial Harem. Trans. Myrna Godzich and Wlad Godzich. Minneapolis: University of Minnesota Press.

Anzieu, Didier. 1989. The Skin Ego. Trans. Chris Turner. New Haven, CT: Yale University Press.

Arnold, Rebecca. 2001. Fashion, Desire, and Anxiety: Image and Morality in the 20th Century. New Brunswick, NJ: Rutgers University Press.

Baudrillard, Jean. 1981. For a Critique of the Political Economy of the Sign. Trans. Charles Levin. St. Louis: Telos.

Benslama, Fethi. 2009. Psychoanalysis and the Challenge of Islam. Trans. Robert Bononno. Minneapolis: University of Minnesota Press.

Bergler, Edmund. 1953. Fashion and the Unconscious. Madison, CT: International Universities Press.

Blos, Peter. 1974. "The Genealogy of the Ego Ideal." Psychoanalytic Studies of the Child, no. 29: 43-88.

Brenner, Suzanne. 1996. "Reconstructing Self and Society: Javanese Muslim Women and "the Veil." "American Ethnologist 24(3):673-97.

Çarkoğlu, Ali, and Binnaz Toprak. 2006. "Değişen Türkiye'de Din, Toplum ve Siyaset" [Religion, society, and politics in a changing Turkey]. Report, TESEV, Istanbul. http://research.sabanciuniv.edu/5851/1/DegisenTRdeDin-Toplum -Siyaset.pdf.

Ceylan, İsmail Fatih. 1992. “Tekbir'in Sahibi Mustafa Karaduman: Amacimız Tesettürü Sevdirmek” [ Tekbir's owner Mustafa Karaduman: Our goal is to make veiling loved]. Milli Gazete, October 10.

Çiftçi, Halise. 1993. "Tesettür, Moda ve Defile” [Veiling, fashion, and the catwalk]. Milli Gazete, April 28.

Copjec, Joan. 1989. "The Sartorial Superego." October, no. 50: 56-95.

- 2006. "The Object-Gaze: Shame, Hejab, Cinema." Filozofski Vestnik27(2): $11-29$.

Deleuze, Gilles. 1994. Difference and Repetition. New York: Columbia University Press.

Eygi, Mehmet Şevket. 2005. "Müslüman Sosyete" [Muslim high society]. Milli Gazete, December 9.

_. 2009. "Müslüman Zenginler" [The Muslim rich]. Milli Gazete, April 21. http://www.mehmetsevketeygi.com/habergoster.asp?id=759.

Fanon, Frantz. 1965. "Algeria Unveiled." In A Dying Colonialism, 35-67. New York: Grove.

Flugel, John Carl. 1930. The Psychology of Clothes. London: L. \& V. Woolf.

Freud, Sigmund. (1923) 1960. The Ego and the Id. Trans. James Strachey. New York: Norton.

Fuss, Diana. 1994. "Fashion and the Homospectorial Look." In On Fashion, ed. Shari Benstock and Suzanne Ferriss, 211-32. New Brunswick, NJ: Rutgers University Press. 
Ghazali, Abu Hamid al-. 1995. On Disciplining the Soul: Kitab Riyadat al-Nafs and on Breaking the Two Desires. Trans. T. J. Winter. Cambridge: Islamic Texts Society.

Gökarıksel, Banu, and Ellen McLarney. 2010. "Introduction: Muslim Women, Consumer Capitalism, and the Islamic Culture Industry." Journal of Middle East Women's Studies 6(3):1-18.

Gökarıksel, Banu, and Anna J. Secor. 2010a. "Between Fashion and Tesettür: Marketing and Consuming Women's Islamic Dress." Journal of Middle East Women's Studies 6(3):118-48.

- 2010b. "Islamic-ness in the Life of the Commodity: Veiling-Fashion in Turkey." Transactions of the Institute for British Geographers 35(3):313-33.

—. 2012a. "'Even I Was Tempted': The Moral Ambivalence and Ethical Practice of Veiling-Fashion in Turkey." Annals of the Association of American Geographers 102(4):847-62.

- 2012b. "'You Can't Know How They Are Inside': The Ambivalence of Veiling and Discourses of the Other in Turkey." In Religion and Place: Landscape, Politics, and Piety, ed. Lily Kong, Peter Hopkins, and Betsy Olson, 95-1 14. New York: Springer.

Hakan, Ahmet. 2008. "Dinsel maskaralık" [Religious ridicule]. Hürriyet, April 23. http://www.hurriyet.com.tr/yazarlar/8765919.asp?m=1.

Hollander, Anne. 1975. Seeing through Clothes. Berkeley: University of California Press.

- 1999. Feeding the Eye. Berkeley: University of California Press.

Jones, Carla. 2007. "Fashion and Faith in Urban Indonesia." Fashion Theory 11(2/ 3):211-32.

- 2010. "Images of Desire: Creating Virtue and Value in an Indonesian Islamic Lifestyle Magazine." Journal of the Middle East Women's Studies 6(3): 91-117.

Kabbani, Muhammad Hisham. 1998. Self-Purification and the State of Excellence: Encyclopedia of Islamic Doctrine. Vol. 5. 2nd ed. Mountain View, CA: As-Sunna Foundation of America.

Kılıçbay, Barış, and Mutlu Binark. 2002. "Consumer Culture, Islam and the Politics of Lifestyle: Fashion for Veiling in Contemporary Turkey." European Journal of Communication 17(4):495-511.

Klepp, Ingun Grimstad, and Ardis Storm-Mathisen. 2005. "Reading Fashion as Age: Teenage Girls' and Grown Women's Accounts of Clothing as Body and Social Status." Fashion Theory 9(3):323-42.

Krips, Henry. 2008. "The Hijab, the Veil, and Sexuation." Pscyboanalysis, Culture and Society, no. 13: 35-47.

Lacan, Jacques. 1998. On Feminine Sexuality: The Limits of Love and Knowledge. Trans. Bruce Fink. New York: Norton.

Lewis, Reina. 2007. "Veils and Sales: Muslims and the Spaces of the Postcolonial Fashion Retail." Fashion Theory 11(4):423-42. 
_. 2010. "Marketing Muslim Lifestyle: A New Media Genre." Journal of Middle East Women's Studies 6(3):58-90.

Mahmood, Saba. 2005. Politics of Piety: The Islamic Revival and the Feminist Subject. Princeton, NJ: Princeton University Press.

Mernissi, Fatima. 1987. Beyond the Veil: Male-Female Dynamics in Modern Muslim Society. Rev. ed. Bloomington: Indiana University Press.

Moors, Annelies. 2007. "Fashionable Muslims: Notions of Self, Religion, and Society in San'a." Fashion Theory 11(2/3):319-46.

_. 2009. “' 'Islamic Fashion' in Europe: Religious Conviction, Aesthetic Style, and Creative Consumption." Encounters, no. 1: 175-201.

Moors, Annelies, and Emma Tarlo. 2007. "Introduction." Journal of Middle East Women's Studies 11 (2/3):133-41.

Nasr, Sayyed Hossein. 1999. Sufi Essays. Chicago: ABC International.

Navaro-Yashin, Yael. 2002. "The Market for Identities: Secularism, Islamism, Commodities." In Fragments of Culture: The Everyday of Modern Turkey, ed. Deniz Kandiyoti and Ayşe Saktanber, 221-53. London: I. B. Tauris.

Ragland, Ellie. 2008. "The Masquerade, the Veil, and the Phallic Mask." Psychoanaylsis, Culture and Society, no. 13: 8-23.

Renard, John. 2009. The A to $Z$ of Sufism. Lanham, MD: Scarecrow.

Saktanber, Ayşe. 2002. Living Islam: Women, Religion and the Politicization of Culture in Turkey. London: I. B. Tauris.

Sandıkçı, Özlem, and Güliz Ger. 2001. "Fundamental Fashions: The Cultural Politics of the Turban and the Levi's." Advances in Consumer Research, no. 28: $146-50$.

- 2005. "Aesthetics, Ethics, and Politics of the Turkish Headscarf." In Clothing as Material Culture, ed. Susanne Küchler and Daniel Miller, 61-82. Oxford: Berg.

- 2007. "Constructing and Representing the Islamic Consumer in Turkey." Fashion Theory $11(2 / 3): 189-210$.

- 2010. "Veiling in Style: How Does a Stigmatized Practice Become Fashionable?" Journal of Consumer Research 37(1):15-36.

Schimmel, Annemarie. 1975. Mystical Dimensions of Islam. Chapel Hill: University of North Carolina Press.

Schulz, Dorothea. 2007. "Competing Sartorial Assertions of Femininity and Muslim Identity in Mali." Fashion Theory 11(2/3):253-80.

Shaikh, Sa'diyya. 2009. "In Search of al-Insān: Sufism, Islamic Law, and Gender." Journal of the American Academy of Religion 77(4):781-822.

Silverstein, Brian. 2008. "Disciplines of Presence in Modern Turkey: Discourse, Companionship, and the Mass Mediation of Islamic Practice." Cultural Anthropology 23(1):118-53.

Şişman, Nazife. 2001. Kamusal Alanda Başürtölüler: Fatma Karabryık Karaosmanoğlu ile Söyleşi [Headscarved women in public space: An interview with Fatma Karabıyık Karaosmanoğlu]. Istanbul: Iz. 
200 I Gökarıksel and Secor

Tarlo, Emma. 2010. Visibly Muslim: Fashion, Politics, Faith. Oxford: Berg.

White, Jenny B. 1999. "Islamic Chic." In Istanbul: Between the Global and the Local, ed. Çağlar Keyder, 77-91. Lanham, MD: Rowman \& Littlefield.

Wilson, Elizabeth. 1985. Adorned in Dreams: Fashion and Modernity. Berkeley: University of California Press.

Yeğenoğlu, Meyda. 1998. Colonial Fantasies: Towards a Feminist Reading of Orientalism. Cambridge: Cambridge University Press. 